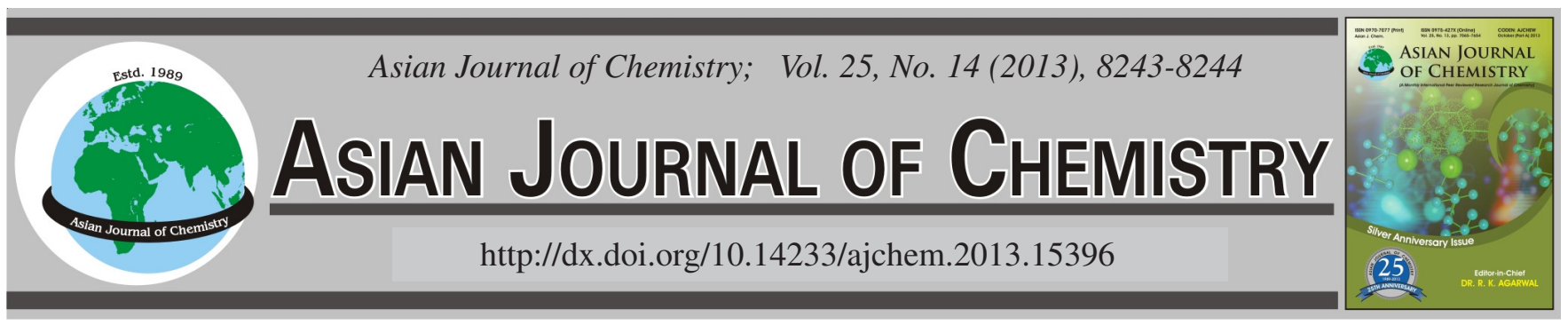

NOTE

\title{
Synthesis and Structural Characterization of a Schiff Base Azamacrocyclic Nickel(II) Complex
}

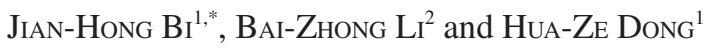

${ }^{1}$ Deparment of Chemistry and Chemical Engineering, Hefei Normal University, Hefei, P.R. China

${ }^{2}$ The Key Laboratory of Materials for High Power Laser, Shanghai Institute of Optics and Fine Mechanics, Chinese Academy of Sciences, Shanghai, P.R. China

*Corresponding author: E-mail: bi010101@126.com

(Received: 27 February 2013;

Accepted: 12 August 2013)

AJC-13924

\begin{abstract}
Schiff base azamacrocyc1ic nickel(II) complex [NiL].SCN.SO $\mathrm{H}_{2} \mathrm{O}(\mathrm{L}=5,5,7,12,12,14$-hexamethyl-1,4,8,11-tetraazamacrocyclic-4,11diene) was synthesized and characterized by IR spectra and single-crystal X-ray diffraction analysis. The crystal belongs to triclinic, space group P-1 with unit cell parameters: $a=7.2678(11) \AA, b=8.9998(13) \AA, c=19.513(2) \AA, \alpha=84.1430(10)^{\circ}, \beta=87.005(2)^{\circ}, \gamma=67.3480(10)^{\circ}$, $\mathrm{V}=1171.6(3) \AA^{3}, \mathrm{Z}=2, \mathrm{M}_{\mathrm{r}}=511.32, \mathrm{D}_{\mathrm{c}}=1.449 \mathrm{Mg} / \mathrm{cm}^{3}, \mu=1.043 \mathrm{~mm}^{-1}, \mathrm{~F}_{(000)}=542, \mathrm{~T}=298(2) \mathrm{K}, \mathrm{R}=0.0375$, wR $=0.0882$ for 6103 reflections with I > 2(I). In the molecular structure unit, the center nickel(II) ion is four-coordinated in a slightly distorted plane square geometry.
\end{abstract}

Key Words: Nickel(II) complex, Schiff base azamacrocycle, Crystal structure.

In recent years, Schiff base azamacrocyc1ic metal complexes have become one of the active research hotspot in the chemical research field ${ }^{1-3}$. They not only have attractive topology structure but also have potential application prospects in stability, catalytic activity, biological activity, magnetic and selective recognition ${ }^{1,4-8}$.

Herein, we described the synthesis and the structural characterization of a Schiff base azamacrocyclic nickel(II) complex $[\mathrm{NiL}] \cdot \mathrm{SCN} \cdot \mathrm{SO}_{4} \cdot \mathrm{H}_{2} \mathrm{O}(\mathrm{L}=5,5,7,12,12,14$-hexamethyl-1,4,8,11tetraazamacrocyclic-4,11-diene).

All the solvents and chemicals were of analytical grade and used without further purification. $[\mathrm{NiL}] \cdot 2 \mathrm{ClO}_{4}$ was prepared according to the literature ${ }^{9}$. IR spectrum was recorded on an Nexus-870 spectromer. The X-ray structure was determined by Siemens SMART CCD area-detector diffractometer.

Synthesis: The $[\mathrm{NiL}] \cdot 2 \mathrm{ClO}_{4}(1 \mathrm{mmol})$ was dissolved in acetonitrile $(10 \mathrm{~mL})$ and $\mathrm{KSCN}(4 \mathrm{mmol})$ and $\mathrm{NiSO}_{4}(1 \mathrm{mmol})$ in $\mathrm{H}_{2} \mathrm{O}(20 \mathrm{~mL})$ were added and the mixture was stirred for $3 \mathrm{~h}$. After being filtered, the solution was stand at room temperature for one week. The dark green four square cylinder crystals were collected, Yield $33 \%$. IR spectrum $\left(\mathrm{KBr}, v_{\max }, \mathrm{cm}^{-1}\right)$ : 3447, 3188, 2056, 1653, 1464, 1398, 1099, 621.

Structure determination: A single crystal $(0.49 \mathrm{~mm} \times$ $0.40 \mathrm{~mm} \times 0.39 \mathrm{~mm}$ ) was selected for crystallographic data collection at 298(2) $\mathrm{K}$ and structure determinated with graphite monochromatic $\mathrm{MoK}_{\alpha}$ radiation $(\lambda=0.71073 \AA)$. A total of
6103 reflections were collected in the range of $2.01^{\circ} \leq \theta \leq$ $25.01^{\circ}$, of which 4062 reflections were unique with $\mathrm{R}_{\text {int }}=$ 0.0187 and $\mathrm{R}=0.0375$ and $\mathrm{wR}=0.0882$, where $\mathrm{w}=1 /\left[\mathrm{s}^{2}\left(\mathrm{~F}_{0}{ }^{2}\right)\right.$ $\left.+(0.0452 \mathrm{P})^{2}+0.5793 \mathrm{P}\right], \mathrm{P}=\left(\mathrm{F}_{0}^{2}+2 \mathrm{~F}_{0}^{2}\right) / 3$. The maximum and minimum peaks on the final difference Fourier map are corresponding to 0.408 and $-0.224 \mathrm{e} / \AA^{3}$ (CCDC No. 925321), respectively.

\begin{tabular}{|c|c|c|c|c|}
\hline \multicolumn{5}{|c|}{$\begin{array}{c}\text { TABLE-1 } \\
\text { NON-HYDROGEN ATOMIC COORDINATES } \\
\left(\times 10^{4}\right) \text { AND THERMAL PARAMETERS }\left(\times 10^{3} \AA^{2}\right)\end{array}$} \\
\hline Atom & $\mathrm{X}$ & $\mathrm{Y}$ & $\mathrm{Z}$ & $\mathrm{U}(\mathrm{eq})$ \\
\hline $\mathrm{NI}(1)$ & $8077(1)$ & $7341(1)$ & $7482(1)$ & $33(1)$ \\
\hline $\mathrm{N}(1)$ & $8810(3)$ & $8445(3)$ & $8118(1)$ & $37(1)$ \\
\hline $\mathrm{N}(2)$ & $8265(3)$ & $5584(3)$ & $8155(1)$ & $36(1)$ \\
\hline $\mathrm{N}(3)$ & $7600(3)$ & $6153(3)$ & $6817(1)$ & $37(1)$ \\
\hline $\mathrm{N}(4)$ & $7731(3)$ & $9145(3)$ & $6817(1)$ & $36(1)$ \\
\hline $\mathrm{N}(5)$ & $1503(5)$ & $7714(5)$ & $5780(2)$ & $90(1)$ \\
\hline $\mathrm{S}(1)$ & $3359(1)$ & 2341(1) & $8739(1)$ & $49(1)$ \\
\hline $\mathrm{S}(2)$ & $2712(2)$ & $5531(1)$ & $6939(1)$ & $74(1)$ \\
\hline $\mathrm{O}(1)$ & $5226(5)$ & $1857(5)$ & $8446(2)$ & $126(1)$ \\
\hline
\end{tabular}

The atomic coordinates and thermal parameters are given in Table-1 and the selected bond lengths and bond angles are given in Table-2, respectively. The molecular structure of the complex is shown in Fig. 1, which contains $[\mathrm{NiL}]^{2+}$ cation and one $\mathrm{SCN}^{-}$anion, one $\mathrm{SO}_{4}{ }^{2-}$ anion and one crystallized $\mathrm{H}_{2} \mathrm{O}$ 


\begin{tabular}{|c|c|c|c|c|c|}
\hline \multicolumn{6}{|c|}{$\begin{array}{c}\text { TABLE- } 2 \\
\text { SELECTED BOND LENGTHS }(\AA) \text { AND BOND ANGLES }\left({ }^{\circ}\right)\end{array}$} \\
\hline Bond & Length & Angle & $\left({ }^{\circ}\right)$ & Angle & $\left({ }^{\circ}\right)$ \\
\hline $\mathrm{NI}(1)-\mathrm{N}(1)$ & $1.880(2)$ & $\mathrm{N}(1)-\mathrm{NI}(1)-\mathrm{N}(2)$ & $92.60(10)$ & $\mathrm{O}(1)-\mathrm{S}(1)-\mathrm{O}(2)$ & $110.6(13)$ \\
\hline $\mathrm{NI}(1)-\mathrm{N}(2)$ & $1.916(2)$ & $\mathrm{N}(1)-\mathrm{NI}(1)-\mathrm{N}(3)$ & $174.53(10)$ & $\mathrm{O}(1)-\mathrm{S}(1)-\mathrm{O}(3)$ & $115.2(9)$ \\
\hline $\mathrm{NI}(1)-\mathrm{N}(3)$ & $1.888(2)$ & N(1)-NI(1)-N(4) & $87.93(10)$ & $\mathrm{C}(2)-\mathrm{N}(1)-\mathrm{NI}(1)$ & $130.8(2)$ \\
\hline $\mathrm{NI}(1)-\mathrm{N}(4)$ & $1.917(2)$ & N(3)-NI(1)-N(2) & $88.02(10)$ & C(4)-N(2)-NI(1) & $114.08(17)$ \\
\hline $\mathrm{S}(1)-\mathrm{O}(1)$ & $1.369(3)$ & N(3)-NI(1)-N(4) & $91.75(10)$ & C(7)-N(2)-NI(1) & 107.86(18) \\
\hline$S(2)-C(17)$ & $1.620(5)$ & $\mathrm{N}(2)-\mathrm{NI}(1)-\mathrm{N}(4)$ & $176.80(10)$ & $\mathrm{C}(10)-\mathrm{N}(3)-\mathrm{NI}(1)$ & $129.9(2)$ \\
\hline
\end{tabular}

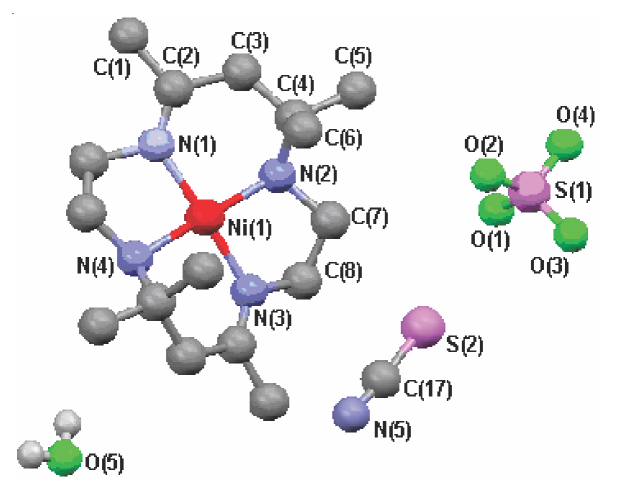

Fig. 1. Molecular structure of the complex $[\mathrm{NiL}] \cdot \mathrm{SCN} \cdot \mathrm{SO}_{4} \cdot \mathrm{H}_{2} \mathrm{O}$

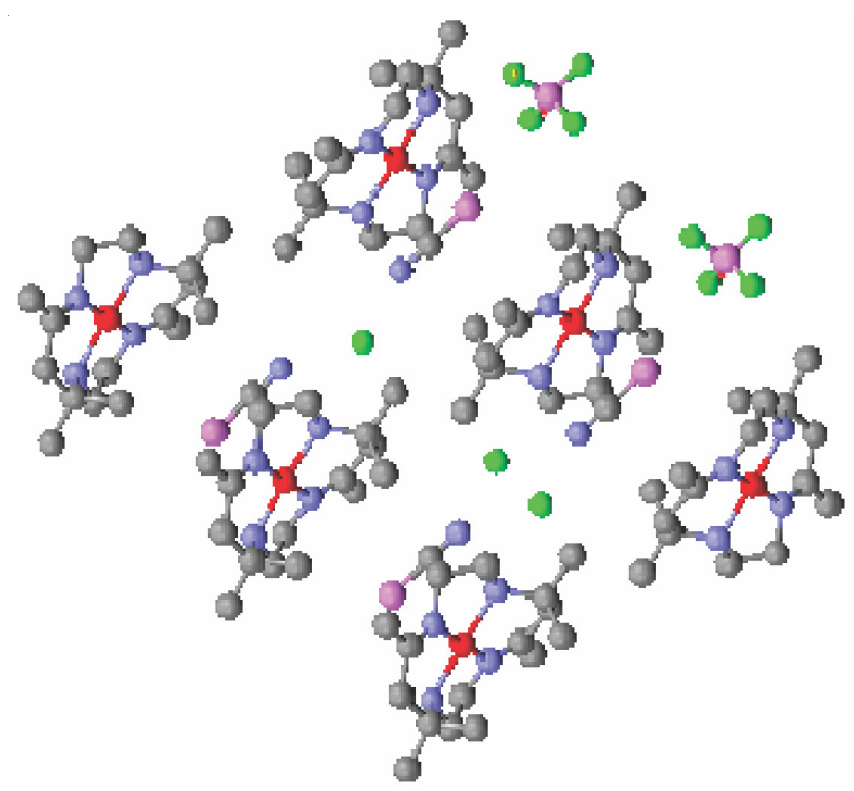

Fig. 2. Molecular packing arrangement in the unit cell molecule. The molecular pack arrangement in the unit cell is shown in the Fig. 2, the center nickel(II) cation is four-coordinated in a slightly distorted plane square geometry. There is a positive negative charge interaction of $[\mathrm{NiL}]^{2+}$ cation with anions of $\mathrm{SCN}^{-}$and $\mathrm{SO}_{4}{ }^{2-}$.

\section{ACKNOWLEDGEMENTS}

This work is financially supported by the Natural Science Foundation of Anhui Province (Nos. 1308085MB23), the National Natural Science Foundation of China (Nos. 20871039 and 21101053) and Key Discipline Foundation of Hefei Normal University.

\section{REFERENCES}

1. J.C. Timmons and T.J. Hubin, Coord. Chem. Rev., 254, 1661 (2010).

2. N.F. Curtis, K. Flood, C.E. Rickard, W.T. Robinson and J.M. Waters, Polyhedron, 28, 739 (2009).

3. J.H. Bi, Acta Crystallogr. E, E65, m668 (2009).

4. R.M. Izatt, K. Pawlak, J.S. Bradshaw and R.L. Bruening, Chem. Rev., 91, 1721 (1991).

5. J.H. Bi, Asian J. Chem., 23, 5171 (2011).

6. E. Tamanini, E.J. Stephen, M.M. Rigby, M. Motevalli, M.H. Todd and M. Watkinson, Chem-Eur. J, 15, 3720 (2009).

7. T. Biver, F. Secco and M. Venturini, Coord. Chem. Rev., 252, 1163 (2008).

8. O. Das, E. Zangrando and T.K. Paine, Inorg. Chem., 50, 8012 (2011).

9. D.J. Szalda and E. Fujita, Acta Cryst., C48, 1767 (1992). 